\title{
'One immense black spot': aerial views of London 1784-1918
}

The London Journal, Vol. 35 No. 3, November 2010, 236-254

Martyn Barber (English Heritage, Swindon, UK)

Helen Wickstead (Kingston University, London, UK)

Aerial imagery is everywhere these days, but before World War I, the aerial view had been experienced by a tiny minority of individuals. Focusing on airborne adventures from Lunardi's first flight over British soil in 1784 to the Royal Flying Corps, this article uncovers the variety within aerial viewing. Aerial views are sometimes understood as inherently map-like and surveillant, as if the airborne viewer always saw in a certain way. However, early balloonists and their passengers describe a London whose aspects could be revealed or disguised, elevated or debased, by different kinds of viewing.

"Now we rise, and the little white streaks, which are the streets, grow narrower still. Travelling still toward the north-east, we attain a height of 5,000 feet - just about a mile. Below us are Vincentsquare, and the great Millbank Prison... In the picture the strange-looking hexagonal star, built up of pentagons, is Millbank Prison.” [Anonymous, 'London from Aloft', Strand Magazine 2 (1891), 495]

One of the first published articles to be illustrated with aerial photographs described the view from a balloon over Millbank Prison. [1][Fig 1] Millbank was famously designed along Benthamite lines a panopticon, built to permit its overseers to look into all divisions of the institution. Working nearly a decade before the Montgolfier brothers first success, Bentham could never have anticipated anyone gazing down on his prison, trumping the visual pre-eminence of the prison government within. Still less could he have foreseen that view being reproduced for readers of a magazine within an article marketing the latest type of cheap 'Detective Camera'. Indeed, this circulating, 'free-floating', commodified vision of aerial photographs might have more in common with our contemporary Google Earth than it does with Bentham's eighteenth century ideal of institutional vision. However, it is our view that each of these instances of aerial vision are separable, and that important differences may be lost if they are reduced to one another. If, for example, we read the Millbank photograph only through a figure of eighteenth century prison design we risk reducing some of its complexity. Aerial views, we argue, are not always the same [2].

Our principal concern in this chapter is with airborne experiences over London, from the first balloon trip to the earliest powered, heavier-than-air flights. Our aim is to contextualise aerial viewing and images of aerial views. This is not just a matter of understanding different modes of flight and the various means used to represent the resulting view. Tempting as it is to assume a linear history of aerial visuality, numerous analyses demonstrate how ways of seeing are historically and culturally situated [3]. The visual practices and discourses represented by, say, a mid-sixteenth century Bird's-eye view, a late $18^{\text {th }}$ century panorama, and a $19^{\text {th }}$ century balloon sketch were markedly different to each other as well as to those that characterise early aerial photography.

The main era of balloon flight over the capital - the nineteenth century - witnessed key developments and discontinuities in visual practices and visual culture. Rising numbers of people were able to experience being airborne; equally significant is the increasing availability during the second half of the century of aerial photographs, bringing a new sense of immediacy and 'reality' to consumers of aerial images. Nineteenth century aerial visualities can also be contextualised more broadly; within histories of the nineteenth century modernisation of the observer [4]; cultural studies of warfare, photography and cinema [5]; and accounts of the connections between nineteenth century capitalism and the subjective capacity to ‘pay attention' [6]. 
The aerial view is commonly understood as both 'panoptic' and 'map-like'. For example, de Certeau's account of 1970s Manhattan is widely interpreted through an opposition between the panoptic, aerial viewpoint of mapmakers and city-planners and the creative approach to space by walkers at ground level [7]. Contextualising the aerial view has implications for this distinction. Consideration of the realities of $19^{\text {th }}$ and early $20^{\text {th }}$ century airborne experiences, and of the longstanding obstacles that prevented aerial photographs becoming part of mainstream cartography, suggests that aerial vision was not always self-evidently 'map-like' - but has become so through a particular historical trajectory [8]. Making aerial photographs amenable to the demands of surveyors, cartographers and planners was a historical process. Stabilising the panoptic capacities of aerial viewing took time and effort. Furthermore, aerial viewing has other possibilities, other 'lines of flight', as it were, which may be neglected when our focus is only on what is map-like and panoptic.

We begin by briefly examining aerial views constructed before humans became airborne. We then examine the experiences of aeronauts both before and after the advent of photography, focusing particularly on aerial views of London. The subsequent age of the aeroplane and industrialised warfare began the transmutation of aerial photography into aerial survey, and the long process that would relate aerial photographs to mapping. We conclude by returning to de Certeau, to the distinction between aerial viewing and ground-based experience and to the figure of the panopticon. But first it is necessary to look briefly at what we might call the 'prehistory' of the aerial view.

\section{Imaginary views}

Imaginary aerial viewing long pre-dates actual flight [9], and imaginary views continued to be produced after the appearance of balloons. In this section, we focus briefly on two particular forms of imagined view - bird's-eye views and panoramas - touching on similarities and contrasts in their visual content.

Changing conceptions of space and place in medieval and Renaissance art led to an interest in depicting landscapes and places from an imaginary, raised vantage point, "an eye that did not yet exist” [10]. These perspective, or bird's-eye, views also owed something to contemporary cartography. By the mid-sixteenth century, such views of major towns and cities were popular and widespread, among those from Britain being a variety of bird's-eye views of London produced by the Prague-born etcher Wenceslaus Hollar. Many of his better-known works, such as his 'Bird'seye Plan of the West Central District of London' (c. 1658) are not maps in the modern sense - they resemble rather than accurately represent their subject. Key and familiar buildings and landmarks, particularly the Thames, were used as a means of fixing spatial relationships on images in which precise measurement was secondary to visual impact [11].

While these bird's-eye perspectives appear to mark a significant shift in vision - a reasoned projection of their subject, seen from an impossible viewpoint - they continued to conform to contemporary visual practices, possessing vanishing points and presenting their subject as a framed and comprehensible entity. A more marked contrast is offered by visual technologies emerging from the end of the $18^{\text {th }}$ century onwards, contemporary with the experiences offered by real flight. Some, such as the Panorama, presented the aerial view as public spectacle. They comprised a large $360^{\circ}$ painting displayed within a specially constructed building, presenting the viewer with the impression of experiencing reality rather than a painted scene.

The idea of the Panorama was patented in 1787 by Robert Barker, one of his first successes being a panoramic view of London as seen from a lofted viewpoint - the roof of the Albion Mills, adjacent to Blackfriars Bridge. Panoramas were quickly and immensely popular across Europe and America, 
and inspired a range of related phenomena (including moving panoramas, Cycloramas, Dioramas, and, ultimately, developments in lantern slide projections and early motion pictures [12]). Bird'seye views were a common subject, situating the viewer at an imaginary viewing point somewhere above the scene being presented to them. Not all these views were 'panoramic' in the sense that Barker originally intended. They still offered a combination of depth, breadth and detail, but didn't provide an all-round view. An example here is the so-called 'Rhinebeck' panorama, which seems to belong to the first decade of the $19^{\text {th }}$ century. Spread across four sheets, and around eight feet in total length, it presents a detailed view of an extraordinarily busy London, the viewpoint located somewhere above the River Thames. [13]

As with the earlier bird's-eye views, Panoramas privileged spectacle over accuracy of detail, with important landmarks establishing a visual framework of reference. At the same time, however, they broke with the traditions of linear perspective contained within those earlier views and, indeed, within eighteenth century landscape painting. The view was no longer a totality contained within a single frame, but an apparently endless landscape that could no longer be grasped within a single gaze [14].

The Panorama and its variations emerged alongside ballooning, and several artists claimed their Panoramas were based on real flight [15]. Correspendence between the Panorama and the balloon seems evident from the fact that much balloon imagery produced before the widespread use of cameras focused on the panoramic view - the $360^{\circ}$ view experienced by the balloonist. Airborne artists were particularly concerned with the spectacle of vision offered by altitude, a spectacle that found willing audiences across a variety of media [16]. However, Panoramas tended to offer a much more oblique view than was encountered from a balloon. The Panorama situated the observer within its subject; the balloon lifted the observer above it, presenting a distinctly unfamiliar perspective, one that the aeronaut could struggle to make sense of. It is the contrasting views of aeronauts that we turn to next.

\section{Aerial views without cameras}

The first successful balloon flight over British soil began in London on 15 September 1784. The basket was occupied by 22 year old Vincent Lunardi, son of a Neapolitan noble, accompanied by a cat, a dog, a pigeon (in a cage), and a chicken (cooked but cold). Less than a year since the world's first ever successful balloon ascent, a crowd estimated to have been as many as 150,000 gathered at the Honourable Artillery Company's grounds at Moorfield to watch the historic event. [17] By all accounts, the situation on the ground was chaotic, but Lunardi managed to lift off, although some in the crowd doubted they would ever see him alive again. Subsequently, an exhilarated Lunardi attempted to convey in words the first real 'bird's-eye view' of the capital:

“The stillness, extent, and magnificence of the scene rendered it highly awful. My horizon seemed a perfect circle; the terminating line several hundred miles in circumference...[London] was so reduced on the great scale before me, that I can find no simile to convey an idea of it. I could distinguish Saint Paul's and other churches, from the houses. I saw the streets as lines, all animated with beings, whom I knew to be men and women, but which I should otherwise have had a difficulty in describing. It was an enormous bee-hive, but the industry of it was suspended. All the moving mass seemed to have no object but myself...

"[H]ow shall I describe to you a view, such as the ancients supposed Jupiter to have of earth, and to copy which there are no terms in any language. The gradual diminution of objects and the masses of light and shade are intelligible in oblique and common prospects. But here everything wore a new appearance, and had a new effect. The face of the country had a mild and permanent verdure, to 
which Italy is a stranger. The variety of cultivation, and the accuracy with which property is divided, give the idea, ever present to a stranger in England, of good civil laws and an equitable administration; the rivulets meandering; the Thames glistening with the rays of the sun; the immense district beneath me spotted with cities, towns, villages and houses, pouring out their inhabitants to hail my appearance; you will allow me some merit at not having been exceedingly intoxicated with my situation.” [18]

Lunardi introduced certain ways of describing the view from above that recur repeatedly in later accounts of flight from the late eighteenth and earlier nineteenth century. He presented "the awful scene" as a totality, a god's-eye view (in this case, Jupiter), the distant circumference of the horizon framing a city that became ever smaller as his balloon ascended. The balloonists that followed Lunardi tended to produce somewhat formulaic reports; they attempted to convey the novelty of the experience, their courage, what it felt like to be airborne and drifting with the breeze, and their impressions of what they could see. The quality of air was a common topic, usually appearing in the form of remarks about the view being impeded by smoke, fog or haze. [Fig 2] Recurring themes in this literature include: miniaturisation of the city and its landmarks, views of the Thames, the haziness of the air, and the feeling of tranquillity - the calm of a well ordered creation whose sense is clarified by distance.

The 'diminution of objects' prompted frequent references to ants and Lilliput, but it was recognition of the major landmarks that provided a framework of reference - Parliament, Buckingham Palace, St Paul's, assorted parks and, of course, the Thames and its bridges. Key structures were used as a means of grasping or presenting the reduced scale of the city as it appeared from a balloon, a process that often meant invoking metaphors or comparisons whose primary purpose was to convey the sense of miniaturisation observed by the balloonists. For example, in a report of a voyage undertaken by Charles Green on Easter Monday of 1825 (during which, he assured readers, he "did not throw out any ballast till he was over the county of Surrey"), Green noted how "The River Thames, with its serpentine form, appeared to the naked eye not larger than a boa-constrictor. When we were at our utmost altitude, St Paul's did not appear to be larger than a dog-kennel, and the monument not bigger than a walking-stick!” [19]

It was the serpentine Thames that most often caught the eye, and the prominence of the river in aeronautical accounts is reminiscent of its foregrounding in earlier bird's-eye view and panoramic representations of the City. For instance, one Henry Beaufoy, Esq., described a balloon journey he undertook from Hackney to East Thorpe in Essex on 2 August 1811. According to Beaufoy, initially "It appeared difficult to persuade the mind that it was a reality; and the mixed sensations of delight and astonishment completely deprived me of the power of expressing my wonder at the scene beneath the eye." Once things had settled down somewhat, "I had an opportunity of viewing at leisure the prospect of the balloon. The first and most striking object was the Thames, which was seen meandering in endless gigantic sinuosities through the long line of country down as far as the Nore. The ships, and even boats, were distinguishable on its mirror-like surface with astonishing minuteness;... The sun shone full upon the river, and presented at once the grandest and most delightful sight imaginable.” [20]

Balloonists wrote as though they believed that the distance achieved by altitude allowed them to see through the surface chaos of the city to gain a better understanding of how things worked. As they adjusted to the novel perspective offered by flight, the apparently map-like arrangements of streets and buildings suggested a sense of underlying order. There seems to have been an emotional connection between this sense of order in creation and the feelings of calm and tranquillity that were often experienced at altitude. The noise of the city disappeared, people and vehicles were barely visible. The balloon car at altitude functioned as a camera obscura, literally distancing the 
observer from his subject. Framed by the horizon, the earth below could be appraised as a single, comprehensible entity.

An alternative framework for aerial experience was supplied by Henry Mayhew, writing in the mid nineteenth century. Mayhew is best-known for his multi-part epic 'London Labour and the London Poor', a detailed study of London's lower classes and street life in the 1840s and 1850s. He accompanied Charles Green on an ascent on 12 September 1852 with an agenda that went beyond merely attaining vertical distance:

"I had seen the great metropolis under almost every aspect. I had dived into holes and corners hidden to the honest and well-to-do portion of the cockney community. I had visited Jacob's Island (the plague spot) in the height of the cholera, when to inhale the very air of the place was to breathe the breath of death. I had sought out the haunts of beggars and thieves, and passed hours communing with them as to their histories, habits and impulses. I had seen the world of London below the surface, as it were, and I had a craving to contemplate it far above it - to behold the immense mass of avarice and cunning, of noble aspirations and humble heroism blended into one immense black spot; to take, as it were, an angel's view of the whole city where, perhaps, there is more virtue and iniquity, more wealth and more want huddled together in one vast heap than in any other part of the earth; to look down upon the strange, incongruous lumps of palaces and workhouses, of factory chimneys and church steeples, of banks and prisons, of docks and hospitals, of parks and squares, of courts and alleys - to look down upon these as birds of the air look down upon them, and see the whole dwindle into a heap of rubbish on the green sward...”. [21]

For Mayhew, vertical distance obscured as much as it revealed. He took great delight in the fact that altitude seemed to remove any clear demarcation between poverty and wealth, disease and health and so on, noting in particular that he could see Buckingham Palace and Bethlehem Hospital in the same view. [22]. The "accuracy with which property is divided", the sense of underlying order any impression of the effective exercise of power and control over the city - are all absent from the aerial gaze as experienced by Mayhew. His effort to convey the experience of being airborne remains focused as much on what he couldn't see as on what he could.

It wasn't just London's social and economic boundaries that were lost to the aerial gaze. From the air "it is difficult to tell where the Metropolis begins, and where it ends, as it is to point out the particular line of demarcation between the several colours of the rainbow; for the suburban villages blend so insensibly into the city, that one might as well attempt to define the precise point where the water begins to be salt at the mouth of some estuary.” [23]

It is interesting to compare written descriptions of aerial vision before cameras with those of the later nineteenth century. The camera emerged from and reinforced visual sensibilities that were not always compatible with the literary tropes of earlier aeronautical texts (tending, for example, to present aerial views as framed fragments rather than total wholes analogous to the bird's eye view). By the 1880s aerial photography was readily achievable, and the aerial view was on the verge of exposure to a far wider audience than had previously been possible. From this period come accounts of aerial vision that undermine, even satirize, earlier aeronautical literature. Whereas for early balloonists the aerial view revealed an underlying order in creation, contemplated in a tranquillity that suggested God was in his heaven and all was well below, in this later period the aerial perspective could be seen as concealing the true London, which was apparent only in the detail encountered at street level.

Reverend John MacKenzie Bacon probably never flew without a camera, and was a prolific publisher of aerial photographs in the years between 1888 and his death in 1904 [Figs 3-5]. He describes his first experience of flight in the early evening of 20 August 1888 when he took off 
from the grounds of Crystal Palace. Echoing (and poking fun at) the grandiose tone of many previous London-from-above texts, he describes the Thames, which:

“...was a truly noble sight. Yes, to us Father Thames was in truth a noble river. What was it to us if his banks were unsavoury and his flood were mud? From our point of view his surface mirrored only the sunlit sky, and up and down to us, his stream was pure silver, and innocent of cats. Lowlying Lambeth looked almost lovely, her Palace part of Paradise - let us hope it is... But it was downstream, below the Docks, below where the Tower stands proudly, that Thames stretched out his grandest reach. Sweep away the bricks and mortar, and where in all England would you find so fair a valley?” [24]

Yet, even if the aerial view obscures the detail necessary for a 'true' picture of the real London (dead cats and all), Bacon also suggests a more holistic perspective than is possible for the earthbound observer. The aeronaut has an anatomical grasp of the city:

“...every great detail of the capital city was mapped out below us...one could grasp as never before what were the lungs of London and what her arteries. For Oxford Street had lost its title to that name; it was the Oxford highway now. The northern tramways were the ways towards York and Cambridge, and Picadilly was the Bath Road. And there were those great arteries that carry England's life-blood to and from her heart. We struck them now, three at once, over Euston, St Pancras, and King's Cross, along which latter line one of the company's splendid trains, going north, was trumpeting." [25]

Early writings demonstrate that there was never just one way of viewing London from the air. Despite the recurrence of certain themes, writers experienced aerial vision in very different ways. For Lunardi it was god-like vision, making plain the 'good civil laws' and 'equitable administration' of England. For Mayhew, it was a melting pot, an 'angel's view', before which all were made equal. For Bacon, it was an image, disguising the true face of London, and a diagram, dissecting the city's anatomy. While Mayhew's account appears to stand in opposition to previous descriptions, like earlier writers he regarded his own view as an objective one - made even more so by his extensive investigations of the city on the ground. Bacon on the other hand offers an element of subjectivity, and a modern appreciation for the deceptiveness of images. What aerial views before cameras have in common is a tendency to treat the balloon as a platform for distanced appraisal. At altitude London could be observed and discussed as a single, bounded entity. After cameras, something about the completeness of this vision was fragmented; it is this period that we turn to next.

\section{Aerial views with cameras}

The first successful aerial photograph was taken in December 1858, when the French photographer Nadar captured an image on a glass plate while tethered a couple of hundred feet above the outskirts of Paris [26]. The first over England followed five years later, during a free flight by Henry Negretti that began at a gasworks in Lower Sydenham. Negretti's photographs, taken above the River Medway, are lost but were described at the time by a correspondent of the Daily Telegraph as 'tolerable' [27].

Nadar was first and foremost a portrait photographer with an approach to his subjects that drew on his earlier career as a caricaturist and sketch artist. He was particularly concerned with developing photography as an art form. However, Nadar's approach to capturing a convincing and sympathetic likeness of Gustave Doré or Sarah Bernhardt, say, was in stark contrast to his claim that accurate surveying and map-making should be the goals of the airborne photographer. He made these intentions clear five years after his first successful photograph when publicising the launch of an 
enormous balloon named Le Géant: "we are not about to amuse ourselves...in making portraits in the air. The balloon....will be employed in various works of aerostatic photography...the results of which will be so valuable for all planispheric, cadastral, strategical, and other surveys.” [28] Ultimately, his achievement was to prove that photography from a balloon was possible, although in this as in many other ventures he seems to have encountered failure as much as success. It was as an aerial photographer rather than as an aerial surveyor that he can be regarded as a pioneer.

It wasn't until the 1880s that aerial photographers began to achieve something approaching regular success, largely due to advances in camera and plate technology. The collodion or wet plate process had meant that both Nadar and Negretti needed to convert part of their balloon cars into darkrooms. The availability of the gelatine dry plate from 1871 ensured that photographers no longer had to prepare, expose and develop their plates within the space of around twenty minutes. However, the real stimulus for aerial photography was more to do with money, adventure, class, and the marketing of easy-to-use cameras. Ballooning was becoming socially respectable. Alongside, and perhaps partly linked to, its increasing use by the military (reconnaissance from a military balloon was the preserve of officers), it was an increasingly fashionable pastime for those with the time, resources and nerve. At the same time, improvements in camera technology saw shorter exposure times and less unwieldy equipment, culminating in the appearance of the first Kodak in 1888. A small, portable box camera with fixed focus and shutter speed, it used a roll of film rather than plates, each capable of taking 100 exposures.

At 5 guineas, the Kodak was far from cheap, but it made practical photography more widely accessible than ever before. It ushered in an era of similar cameras, their small size, portability and ease of use allowing more surreptitious photography than previously possible. These cameras were often talked of generally, and some were marketed specifically, as 'detective cameras'.[29] However, while the properties that made them ideal for street-level surveillance, snooping and voyeurism were broadly similar to those that appealed to the balloonist, the reasons were rather different. Lightweight and easy to carry, these cameras were perfect for lighter-than-air flight. Their potential for concealment was irrelevant - a balloon was hardly an unobtrusive platform for photography, especially if people rather than places were to be the recognisable subject of photographic images.

Balloon photography, even when firmly linked to the use of 'detective cameras', never seems to have prompted ethical debate in the same way that the more everyday use of these hand-held devices did. Anecdotes relating to spying or surveillance from balloons outside the military are rare, and those that do exist belong mainly to the period before cameras. For example, an anonymous Liverpudlian who flew over London with Charles Green in 1835 included the following exchange between himself and Green in his account of the voyage:

"Do you see a smart chariot crossing the square?”

"Plainly."

"The man in the chariot is going down to the House of Lords by one road, the man in the cab is going by another to my lord's house, where he purposes to console my lady in her husband's absence. If you keep your eyes upon them you will find what I say is true - you cannot think what odd things I see when I am hovering over this great town.” [30]

Assuming the conversation actually took place, we must attribute a fair degree of prior knowledge to Charles Green. 
During the 1890s it also became a lot easier and much cheaper to reproduce photographs in books and magazines. The introduction of the half-tone process contributed directly to the growth in the number and popularity of illustrated magazines, and articles featuring aerial views were more common than ever before. Aerial views were presented as illustrations - instantaneous snapshots offering a glimpse into the balloonists' world. But there was no longer any attempt to present something as vast as London as a totality. Instead, the focus was the journey. The landmarks that had once offered a frame of reference within that totality now became the objects of aerial vision in their own right, each captured, framed and described within a single photographic image.

Among the first publications reproducing aerial photographs was 'London from Aloft', an illustrated article in the second volume of Strand magazine. [31] As was often to be the case, the balloon flight - which took place on 9 May 1891 - was presented as an adventure, the camera being used to record the views from above "for those who will not easily be persuaded to practical balloonacy.” [32] In fact, it reads more like an extended advertisement for the latest Kodak 'detective camera'.

The article made it clear that more than a century after Lunardi's flight, a balloon could still attract a sizeable crowd, for whom watching the balloon ascend and gradually disappear into the distance was as fascinating as the experience of flight was for the occupants of the basket. The text described the flight from lift-off in the grounds of the Royal Hospital, Chelsea, to the landing some hours later near Newmarket. It is mainly concerned with what could be seen beneath the balloon, and in particular with what could be seen in the photographs illustrating the article.

The writer noted and described Millbank Prison in the sixth photograph to be taken [Fig 1], alongside other well-known landmarks rendered unfamiliar by height and therefore needing to be explained: "The small round white things, near the prison, which look like iced birthday-cakes, are great gasometers; to the right of the picture the river is seen, with Lambeth, Westminster, Charing Cross, and Waterloo Bridges; the darker patch up the picture, on the left, where the smoke and mist begin to obscure the detail, is St James's Park; on the south side of the river, St. Thomas's Hospital may be discerned, by the foot of Westminster Bridge; and by the other end of the same bridge are the Houses of Parliament.” [33]

The tendency towards more fragmented visualities was already apparent before the appearance of detective cameras [34]. However, new cameras, combined with new processes for printing photographs, contributed to the decline of imagery presenting London as a complete whole. Henceforth, London from above appeared as a sequence of images - details of the city always escaping out of the frame. Simultaneously, some of the earliest aerial photographers had seen, in the realities captured on their exposed plates, the basis for a new approach to map-making. As we have seen, Nadar saw aerial photography as a surveying technology. He was singularly unsuccessful in obtaining results but, as camera technologies improved, others began to experiment along similar lines. It is these would-be aerial surveyors that we focus on next.

\section{Aerial views and cartography}

What was probably the first successful true vertical aerial photograph - i.e. one in which the camera is pointing straight down at the ground, resulting in what is often described as a map-like view was taken over London in the summer of 1882. Shortly afterwards Cecil Shadbolt described the experience to readers of the British Journal of Photography. With his head beneath his 'focusing cloth', Shadbolt kept at least one eye on the scene below as "gradually and steadily the earth appeared to recede from us, while our aerial 'craft' seemed to hang motionless in space, and in a few moments we were almost directly over Hornsey Station of the Great Northern railway... My third and most successful 'shot' was taken shortly afterward, when just over the district of Stamford 
Hill, at which point the barometer recorded an altitude of 2,000 feet. In the resulting picture the streets, railways and houses below are clearly distinguishable. In this view, also, can be seen the vehicles beneath, while people walking on the pathways, although too small to be recognisable, are nevertheless to be distinguished.” [35]

Shadbolt's camera was fixed to the outside of the balloon car with the lens pointing straight down in order to obtain as true a vertical image as possible. Balloon photography was still a hit and miss affair at this point. Shadbolt exposed several plates during the flight, but only seems to have allowed one to escape into the public domain. The result was entitled 'an instantaneous map photograph'.

For photographers, the applicability of aerial photographs to mapping seemed obvious. The photograph, as they generally understood it, captured a slice of reality from above - which, surely, was also the aim of the map-maker. For nineteenth and early twentieth century cartographers, however, the usefulness of aerial photographs was much less apparent. Surveyors already had a tried and tested repertoire of ground-based techniques, and aerial photography did not immediately fit into it. Critically, the 'slice of reality' in a photograph was not subject to the forms of verification cartography deployed. Aerial photographs may have been 'real' but they could not be made meaningfully concrete in established cartographic method.

The first photographer to take an aerial photograph - Nadar - was quick to spot mapping as a potential commercial opportunity. His patent application, made in Britain and dated 29 October 1858, referred to "an entirely new system of photography, whereby photographic bird's-eye views of portions of the earth's surface may be taken, and consists in fitting a photographic camera in a vertical position, with the lens downwards, into the bottom or the side of the car of a balloon” [36].

Exactly how Nadar planned to convert these photographs into something cartographically useful is unclear. He may have been relying on the camera to capture an objective representation of areas of the ground and everything upon it, not realising that this, in itself, would not turn a photograph into a map. The manner in which Nadar publicised his activities, and presented them as spectacle, suggests he was continually trying to convert novel photographic practices and techniques into something commercially useful. In the event, the difficulties of early balloon photography made Nadar's scheme unfeasible. Conditions in a balloon basket were rather different to those in a studio: movement - whether spinning or simply the speed of travel - led to many a blurred image, while escaping gas was an ever-present threat to anyone trying to expose a plate. Furthermore, the balloonist had no real control over the direction of travel and often struggled to maintain an appropriate altitude.

The later $19^{\text {th }}$ century saw some interesting experiments in applying aerial photography to mapping, though as with Nadar, none had any long-term impact. Henry Elsdale, an officer in the Royal Engineers' balloon section, was experimenting as early as 1881. He devised and patented in outline an automatic camera capable of changing plates either at pre-set intervals or via a cable passed through the tethering rope. The camera itself was suspended beneath a small, unmanned balloon. During the 1880s, Elsdale tried unsuccessfully to persuade the Ordnance Survey that there was some future in producing or updating maps from vertical aerial photographs. [37]

Because of Elsdale's experiments, the British Army rejected an offer of a similar camera from a civilian inventor - Walter Woodbury - who was attracted to aerial photography after recognising its military potential for reconnaissance and surveillance. As with Elsdale's invention, the camera would have been capable of taking a succession of aerial views. Interestingly, Woodbury intended using a roll of film rather than plates. Rejection by the military seems to have been matched by a lack of interest generally in his invention. [38] 
Like other photographers, Elsdale understood the value of aerial photography to be the way it captured a slice of 'reality':

"Why should surveyors toil day after day, and week after week, in the detail surveys of towns, villages, thickly enclosed country, harbours, fortifications, cantonments, or other objects, in order to give us a result that has to be transferred to paper by a tedious process of recording, plotting, tracing, examining and drawing, involving at each and every stage, more labour and more openings for that besetting error and imperfection which is inevitable in all human work; if by one single momentary opening of an automatic shutter in our balloon suspended camera, we can in perhaps the $50^{\text {th }}$ or $100^{\text {th }}$ part of a second, seize and stereotype this whole picture by a process which eliminates at once each and all of these numerous stages with their corresponding elements of error; and which, if the picture be then too small for our purpose, enables us to enlarge it to any required scale, by a similar process, whose accuracy is independent of the human operator, and requires only an instrumental perfection, which can be tested and arranged far in advance to any required extent?” [39]

Like many other later nineteenth century photographers, Elsdale regarded the aerial photograph as an uncontestable representation of reality, but it was a reality that presented problems to cartography. Elsdale went to great lengths in the early 1880s to demonstrate the value of using balloon photography for survey purposes, using vertical photographs taken from his own unmanned balloons to both correct and update the Ordnance Survey's mapping of the barracks at Halifax, Nova Scotia. Elsdale wasn't put off by the fact that many of the photographs he took simply weren't good enough - he produced enough successful examples to satisfy himself of the potential of aerial survey. His failure to convince the Ordnance Survey's Director and Officers had more to do with the practical and technical difficulties aerial photography, as a method, presented to ground-based cartography. Sloping terrain caused difficulties - vertical photography is notorious for its tendency to flatten the contours of its subject; important detail could be concealed from view; shadows could add to the confusion, as could the presence of differentially coloured or shaded surfaces. Aerial photographs could not be used to identify boundaries, divisions between individual houses in a terrace, the limits of tidal waters, high water marks, the direction of streams, the names of places and things, and so on. As the Ordnance survey made clear in their correspondence, they believed survey was best carried out on the ground. Despite the efforts of photographers inside and outside the military, $19^{\text {th }}$ century aerial photography failed to gain acceptance as a tool for surveying and mapping

For aerial photography to be integrated with mapping, rather than simply being 'map-like', it needed to become part of the recognised procedure of aerial survey. The techniques of aerial survey emerged after 1914, as a range of technologies and skills were brought together in circumstances where it was only possible to map terrain remotely. Aerial survey linked photography to the development of established procedures for photographic interpretation including analysis using a stereoscope and mapping skills. It was at this time that the aeroplane became an important platform for photography. The aeroplane and the development, in 1915, of aerial cameras with rapid platechanging mechanisms made overlapping sequential photographs - the crucial requirement for stereo-photography from aeroplanes - attainable [40].

Aerial photography and aerial survey are heavily involved in modern cartography. However, as the nineteenth century examples presented here show, an aerial photograph is not the same as a map, and aerial photography is not the same as aerial survey. The aerial photograph did not provide what nineteenth century cartographers wanted, even though the ingredients that subsequently allowed aerial survey to develop were already in existence. It took a war to bring together the various practices, technologies and networks necessary to align aerial photography with cartography. Even 
after the end of the First World War the Ordnance Survey did not see a place for aerial photography in peace-time mapping - save for some very exceptional circumstances [41].

\section{Conclusions}

De Certeau's account of viewing Manhattan from the top of the World Trade Center captures something of the euphoria that early aeronauts experienced when looking down from altitude for the first time. He comments on the presence of a "wind-stirred haze" before using a series of metaphors - based around the rise and fall of the sea - to capture a sense of his own vision. Then, "For a moment, the eye arrests the turbulence...the vast mass freezes under our gaze", and he recognizes a process, "a kind of distancing [which] produces the space planner, the city planner or the mapmaker." [42] De Certeau's imperfect gaze is closer to the experiences of the nineteenth century aerial photographers than to the aerial views of modern planners and map-makers. Nineteenth century cartography had no place for the aerial view - maps were created through engagement with their subject on the ground. The accommodation eventually reached between aerial photography and mapping relied upon the creation of an assemblage of practices that mediated between aerial vision and the earth-bound activities of cartographers. The creation of a map-like, panoptic aerial view actually depended on the partial overcoming of de Certeau's distinction between walking the city and viewing it from above.

Aerial views, we have argued, are not always the same. The many and varied aerial image-making practices and aerial visualities are historically and culturally situated, each possessing complex histories whose inter-relationships are seldom straightforward. The aerial view is contextual. So are the practices of mapping and cartography, as Lynda Nead has demonstrated for mid-nineteenth century London [43]. The various forms of aerial view discussed here - the bird's-eye view, the panorama, the balloon sketch, and the photograph - represent different ways of seeing and comprehending. Each alone apprehended a different way of seeing. There was no single balloon view of London, as the cases of Lunardi, Mayhew, Bacon and others make clear. 


\section{Notes}

1. Anonymous, 'London from Aloft', in The Strand Magazine 2, 1891, 493-8.

2. This article originated in research undertaken for a forthcoming book - M. Barber, 'Mata Hari's Glass Eye and Other Tales: a history of aerial photography and archaeology, to be published by English Heritage (Swindon) in the Spring of 2011 - and was written alongside another article - H. Wickstead and M. Barber, 'A Spectacular History of Survey by Flying Machine' (forthcoming). Both of these cover some of the episodes and issues relating to the history and development of the aerial view in more detail.

3. See for example J. Berger, Ways of Seeing (1972); M. Baxendell, Patterns of Intention: On the Historical Explanation of Pictures, (1985); J. Crary, Techniques of the Observer: On vision and modernity in the nineteenth century, (Cambridge, Mass., 1990).

4. Crary, Techniques of the Observer.

5. P. Virilio The Vision Machine (Bloomington, Ind., 1994).

6. J. Crary, Suspensions of Perception: Attention, Spectacle and Modern Culture (2002).

7. M. de Certeau, 'Practices of Space', in M Blonsky (ed.) On Signs: a semiotics reader, (Oxford, 1985), p122-145; and M de Certeau, The Practice of Everyday Life (Berkeley, 1988), especially chapter VII: 'Walking in the city'.

8. For a critique of uses of panopticism in understanding vision, see D. Murakami Wood, 'Beyond the Panopticon? Foucault and Surveillance Studies', in J.W. Crampton and S. Eldon (eds.) Space, Knowledge and Power: Foucault and Geography (Aldershot, 2007), 245-263. For a critique of linear histories of vision and assumed panopticism within archaeology, see H. Wickstead, 'The Uber Archaeologist: Art, GIS and the male gaze revisited', Journal of Social Archaeology, vol 9:2 (2009), 249-271.

9. Views from imagined aerial positions extend back into prehistory. For example, claims have been made for the so-called 'Bedolina Map', a prehistoric rock art panel from Valcamonica, northern Italy, (see L. Bevan, Worshippers and Warriors: reconstructing gender and gender relations in the prehistoric rock art of Naquane National Park, Valcamonica, Brescia, Northern Italy, BAR S1485 (Oxford, 2006). Written accounts of views from imagined high locations exist throughout history. Famous examples include the 'faire fielde ful of folke' from Langland's Visions of Piers Plowman W. Langland, Visions of Piers Plowman: 'B' text, trans. A.V.C. Schmidt, 1995). The connection between aerial viewing and evil omniscient power goes back to the New Testament temptation of Christ: the devil takes Jesus to a high place from which "all the kingdoms of the world" are instantly visible (see Luke 4:5-7, Matthew 4:1-11).

10. De Certeau, Practices of Space), p124.

11. C. Wall, The Literary and Cultural Spaces of Restoration London, (Cambridge, 1998), especially chapter 3; C. Wall, 'Grammars of Space: the language of London from Stow's Survey to Defoe’s Tour, in The Philological Quarterly 76:4 (1997), 387-411.

12. A. Griffiths, '”Shivers down your spine”: Panoramas and the origins of the cinematic reenactment', Screen 44 (2003), 1-37; D. B. Clarke and M. A. Doel, 'Engineering space and time: moving pictures and motionless trips’, Journal of Historical Geography 31 (2005), 41-60. 
13. For the Rhinebeck panorama, see, for example, J. Bold, T. Hinchcliffe and S. Forester, Discovering London's Buildings with Twelve Walks (2009) p32.

\section{Crary, Suspensions of Perception.}

15. For Panoramas, and variations on the panorama theme, including the remarkable 'Aeronautikon', see E. Huhtamo, 'Aeronautikon! or, the journey of a balloon panorama', in Early Popular Visual Culture 7:3 (2009), 295-306. Rather than surrounding a spectator with an all-round view, the balloon panorama generally followed a journey using vertical or horizontal moving rolls. The scenery presented to the viewing public appears to have been oblique rather than vertical.

16. A late example of a panoramic balloon view was published in The Graphic (31 May 1884), 530; the artist, H.W. Brewer, gave an insight into how such drawings might be constructed.”The large bird's-eye view [was] compiled and worked out by sketches from Nature. The general idea of the drawing was derived from a sketch taken from a balloon by one of our artists. Owing, however, to the rate at which the balloon passed over London it was found impossible to obtain sufficient detail. But this want has been supplied by sketches taken from the Victoria Tower, Westminster Abbey, the Shot Towers, and the top of a house in Westminster”. More remarkable was an imaginative view of the same scene in 1584. See Figure 6 in John Bold's article in this issue.

17. The best source for the adventures of early balloonists remains L.T.C. Rolt's The Aeronauts. A History of Ballooning 1793-1903 (Gloucester, 1985).

18. Vincent Lunardi, An Account of the First Aerial Voyage in England, in a series of letters to his guardian, Chevalier Gherardo Compagni, Written under the Impressions of the various Events that affected the Undertaking (1784, $2^{\text {nd }}$ edn). The page numbering in the copy we consulted is somewhat erratic. The quoted passage begins on p.40, which is followed by pp. 33 and 34 .

19. Charles Green and George Green, 'Messrs Green's Account of their Voyage', in The Circulator of Useful Knowledge, Literature, Amusement, and General Information, No. XVI(16 April 1825), 242, their emphasis.

20. Henry Beaufoy, 'Journal during an Aerial Voyage from Hackney to East Thorpe, Essex, August 2, 1811', in The New Annual Register, or General Repository of History, Politics, and Literature for the Year 1814 (publ. 1815), 237-246.

21. Henry Mayhew, 'In the Clouds, or the Account of a Balloon Trip with Mr Green', reprinted in P Haining, The Dream Machines: An Eye-Witness History of Ballooning (London, 1972), p80.

Originally published in the Illustrated London News, (18 Sep 1852).

22. Henry Mayhew and John Binny, The Criminal Prisons of London and Scenes of London Life, consulted at http://www.victorianlondon.org/publications5/prisons/htm (accessed 23 September 2010).

23. Ibid.

24. Quoted in Gertrude Bacon, The Record of an Aeronaut, being the Life of John M. Bacon (1907), 159-60.

25. Ibid., 160. 
26. Details on the adventures of early aerial photographers can be found in M. Barber (forthcoming) Mata Hari's Glass Eye and Other Tales: a history of aerial photography and archaeology (Swindon).

27. Quoted in B. Newhall, Airborne Camera: the world from the air and outer space (1969), 29.

28. Ibid., p31.

29. For a recent look at the 'detective camera' in the late $19^{\text {th }}$ century see L. Nead's The Haunted Gallery. Painting, Photography, Film c. 1900 (2007), Chapter 3.

30. Anonymous, 'A Trip Over London', in The New Monthly Magazine and Literary Journal (1835), Part the Third, 164-171 (quote on 169).

31. Anonymous, 'London from Aloft'.

32. Ibid., p493.

33. Ibid., p495-6.

34. Crary, Suspensions of Perception.

35. Shadbolt details and quotes from Newhall, Airborne Camera, p36-7; and The Photo-Miniature: A Magazine of Photographic Information, 5:52 (1903).

36. Patents for Inventions: Abridgments of Specifications relating to Photography (1861), 123-4. Nadar's application in the UK, for provisional protection only, was made on his behalf by one John Henry Johnson.

37. M. Barber, 'Aerial photography and the Ordnance Survey. An Episode from the 1880s', Sheetlines, the journal of the Charles Close Society for the study of Ordnance Survey Maps, No. 76 (2006), 6-13.

38. Details on Woodbury from Dictionary of National Bibliography, online version; Royal Engineers Journal XI (1881), 248-9; Newhall, Airborne Camera, 34-5; The Times (18 Feb 1879), 10 .

39. Captain H. Elsdale, RE, 'Balloon Photography from Small Balloons, and its applications in war and peace, memorandum 1', Royal Engineer Committee Extracts for 1883, appendix no. 1 (18 Oct 1882), p19. For further detail on Elsdale's work and military balloon photography generally, see also Barber, 'Aerial photography'; and Barber, Mata Hari’s Glass Eye and Other Tales.

40. See Barber, Mata Hari's Glass Eye and Other Tales; and Wickstead \& Barber, 'A Spectacular History of Survey by Flying Machine'.

41. Ibid.

42. De Certeau, 'Practices of Space’, 122.

43. L. Nead, Victorian Babylon. People, streets and images in nineteenth-century London, (2000), particularly Part 1: 'Mapping and movement'. 


\section{Captions}

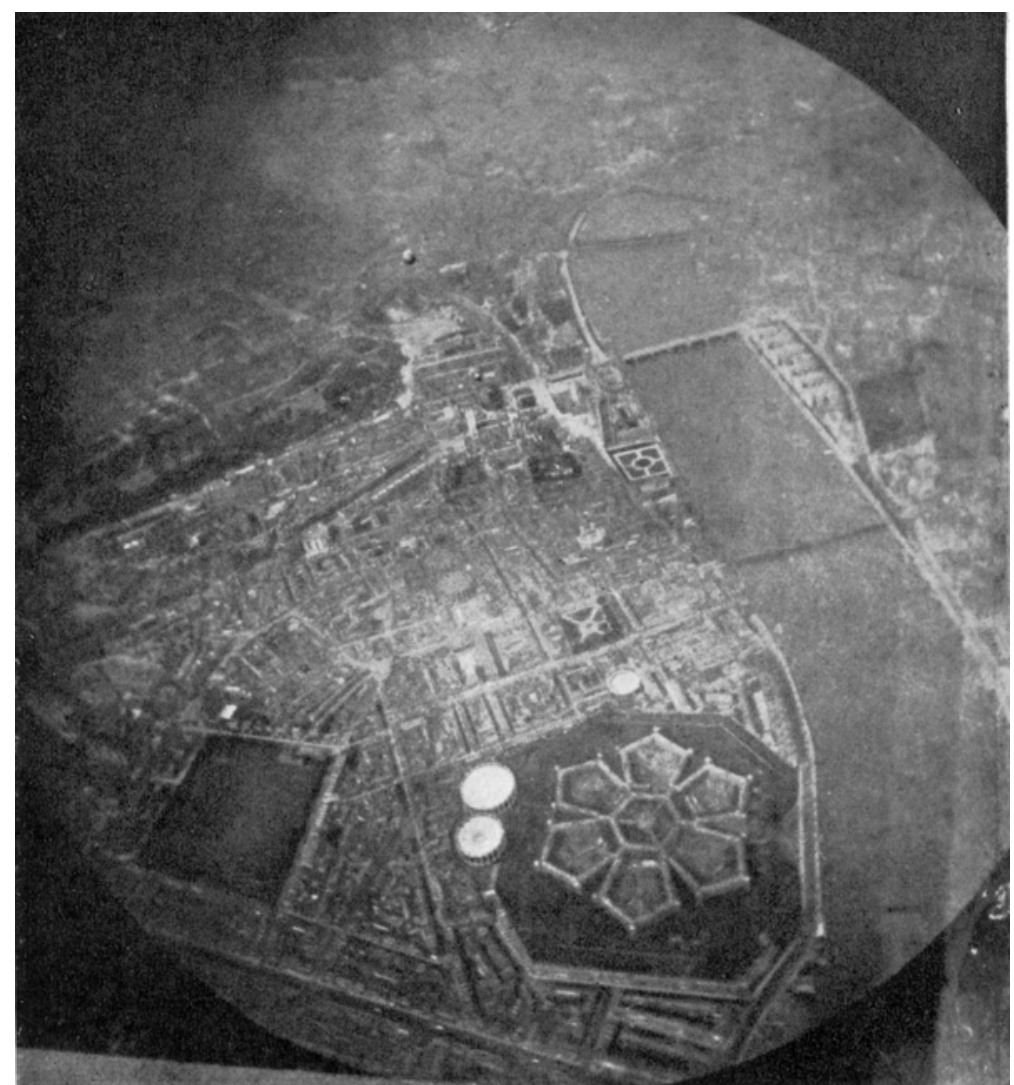

Fig 1. The panopticon viewed from above: Millbank Prison and environs, 9 May 1891, photograph by Griffith Brewer. This image is taken from the article in the Strand Magazine. Note that the early Kodaks produced circular images.

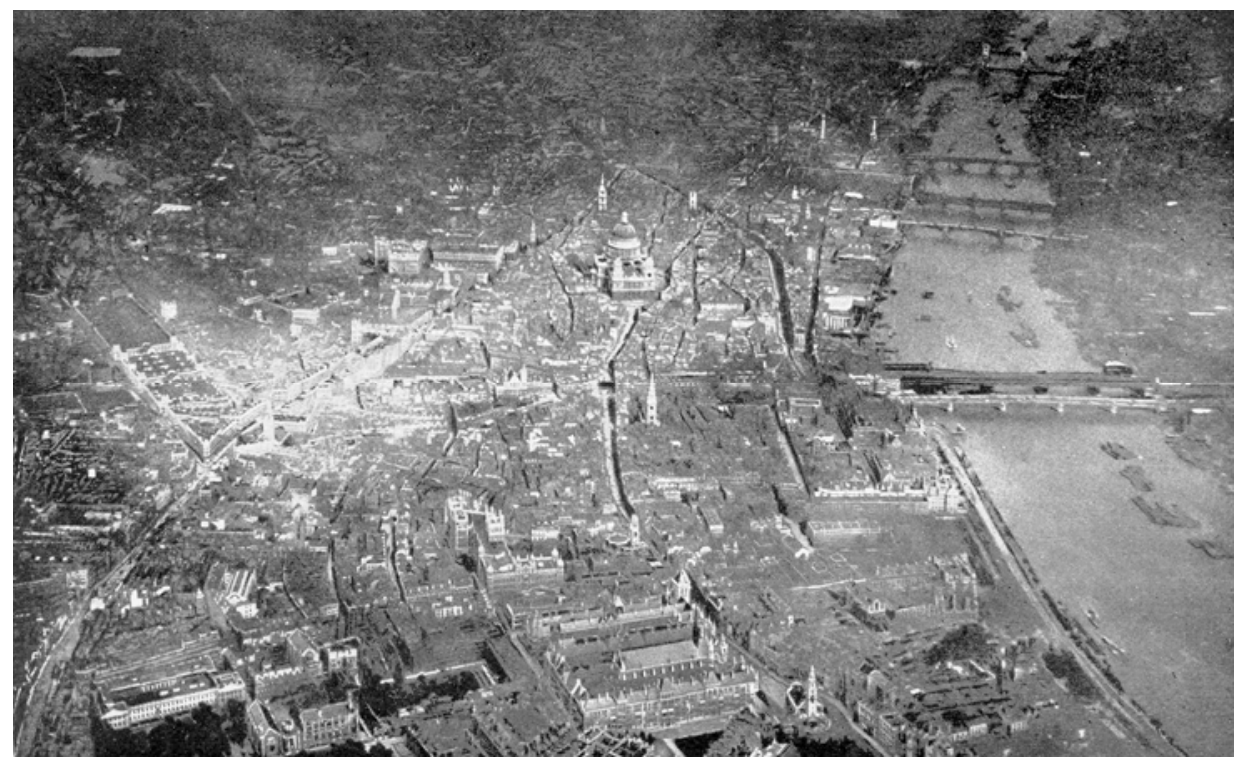

Fig 2. 'Haze lying over the city', undated, by John MacKenzie Bacon. Visibility over the capital was often commented on by balloonists, along with the more breathable air encountered at altitude. Bacon's flying career, and therefore his photographs, all belong to the period 1888-1904. 


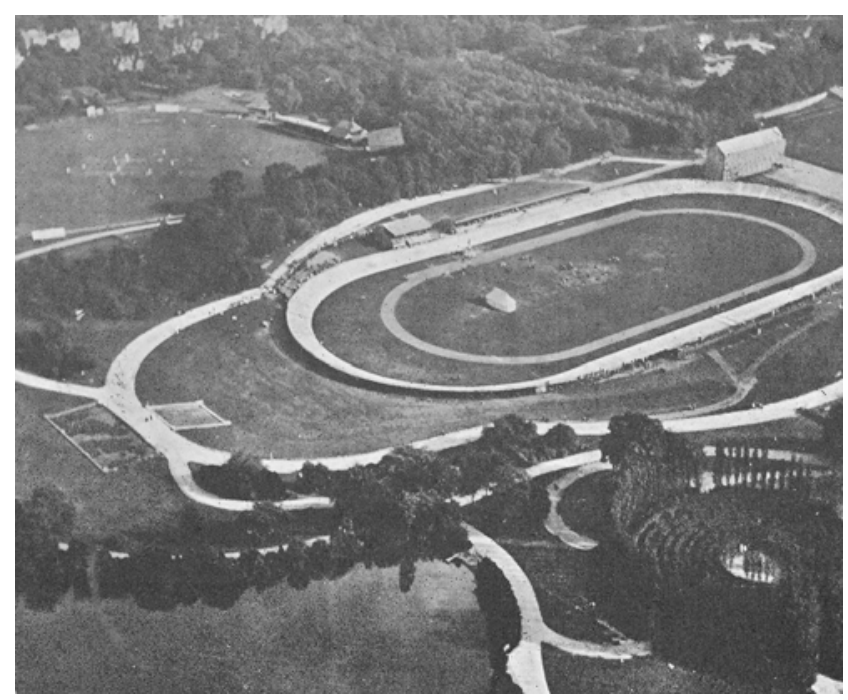

Fig 3. The cycle track in the grounds of the Crystal Palace, undated, by John MacKenzie Bacon.The Crystal Palace was venue for frequent balloon flights during the nineteenth century. Even Nadar semi-inflated his giant balloon there in 1863.

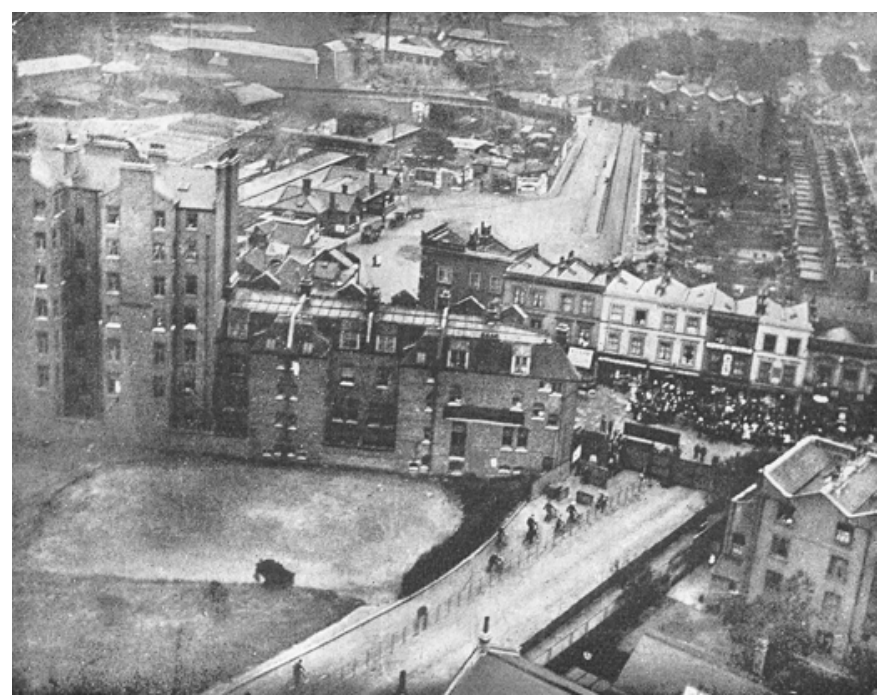

Fig 4. 'Balloon vs. cycle race, Fulham', 30 August 1902, by John MacKenzie Bacon. Bacon’s adventures occasionally led to photographs of areas away from the major landmarks. This particular flight took off from Stamford Bridge, pursued by cyclists. 


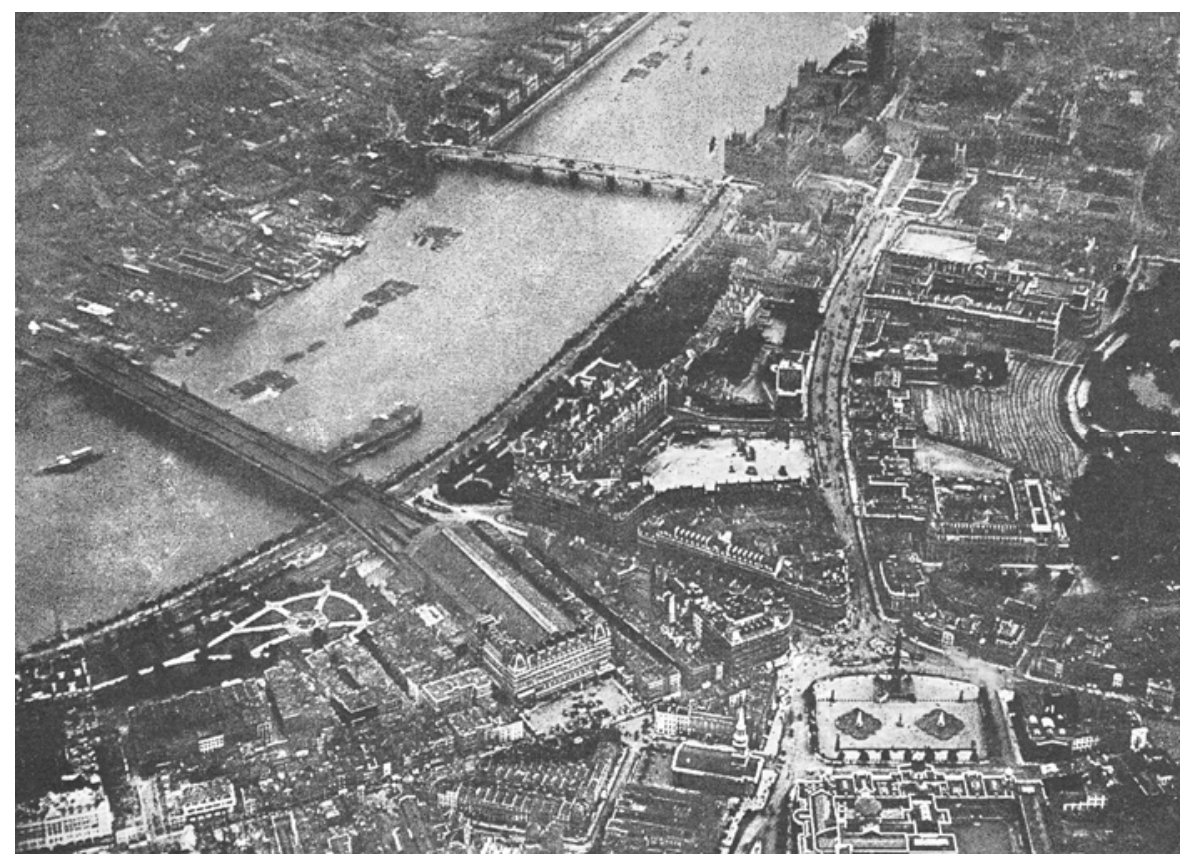

Fig 5. '2000 feet above Trafalgar Square', probably August 1901, by John MacKenzie Bacon. Bacon probably took hundreds of aerial photographs, and published dozens, but rarely offered any direct comment on them.

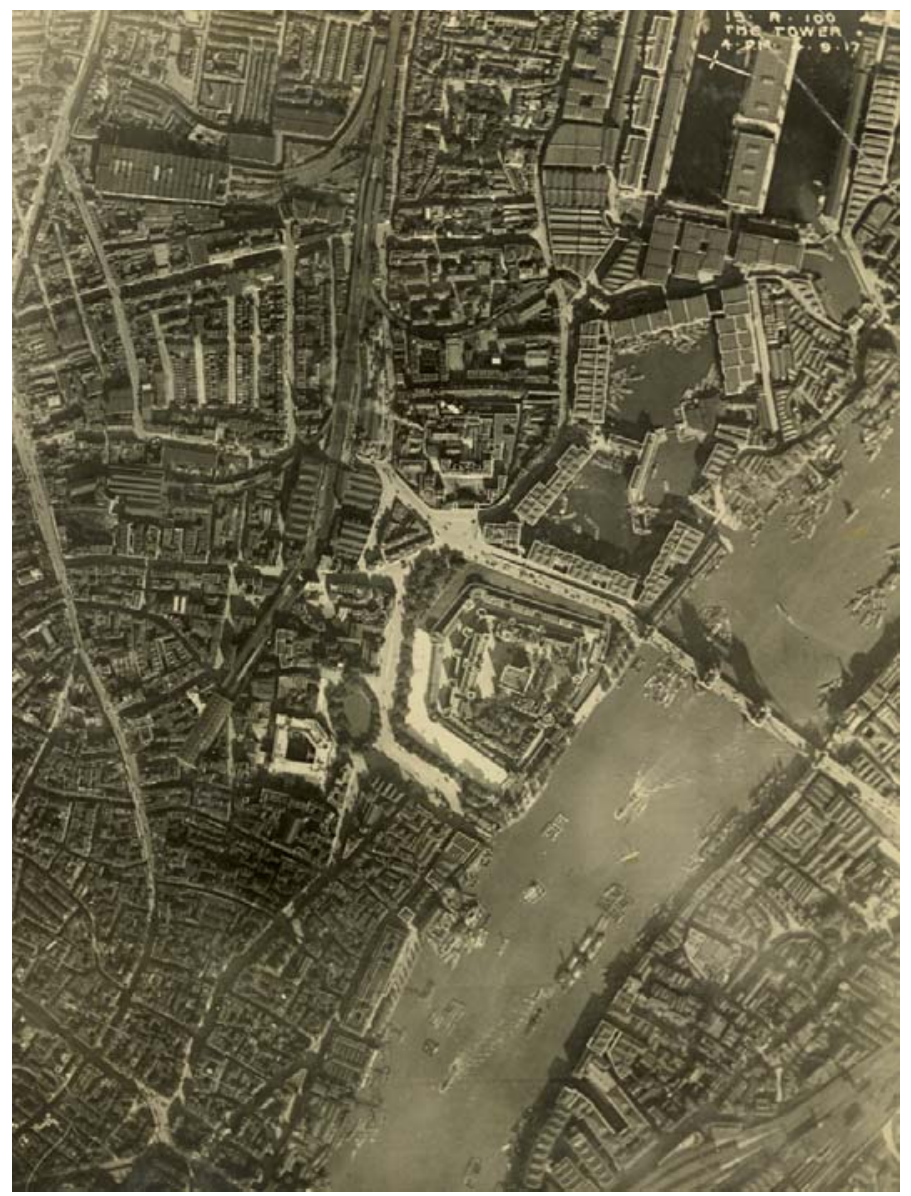

Fig 6. The Tower of London, 4pm on 4 September 1917, by an unknown Royal Flying Corps photographer. By now, military aerial photography was deeply embedded within cartographic practice, with the emphasis on high-quality vertical views. Ideally, successive plates would overlap to obtain a three-dimensional view through a stereoscope. Charles Pulman Collection. Courtesy of Jane Mills. 